\title{
AHLAKÎ KİMLİK ALGISI, BAĞLAMSAL PERFORMANS VE ÖRGÜTSEL ÖZDEŞLEŞME ARASINDAKİ İLIŞKIILERİ BELİRLEMEYE YÖNELİK BİR ÇALIŞMA ${ }^{1}$
}

A. Asuman AKDOĞAN 2

Ayşe CINGÖZ 3

Onur KÖKSAL 4
Received Date (Başvuru Tarihi): 19/02/2020

Accepted Date (Kabul Tarihi): 23/09/2020

Published Date (Yayın Tarihi):

Çalıșmada ilk yazar Sorumlu Yazar (Corresponding Author) rolündedir.

ÖZ

Anahtar Kelimeler:

Ahlakî Kimlik,

Bağlamsal Performans,

Örgütsel Özdeşleşme

JEL Kodlarn:

M1, M19, D23
Bu çalışmanın amacı, ahlakî kimlik algısının bağlamsal performans üzerindeki etkisinde örgütsel özdeşleşmenin düzenleyicilik rolünü tespit etmektir. Bu amaçla, Kayseri Organize Sanayi Bölgesinde faaliyet gösteren sanayi işletmelerinin çalışanlarndan anket aracılığıyla toplanan veri, çeşitli istatistik yöntemler aracılĭ̆ıyla analize tabi tutulmuştur. Yapılan analizler sonucunda yüksek düzeyde örgütsel özdeşleşme yaşayan bireylerde ahlakî kimlik algısının bağlamsal performans üzerindeki etkisinin azaldı̆̆ı, düşük düzeyde örgütleriyle özdeşleşen bireylerde ise ahlakî kimlik algısının bağlamsal performans üzerindeki etkisinin arttı̆̆̆ bulunmuş̧ur. Elde edilen bulgular ilgili alan yazın bağlamında tartışılmıştır.
Keywords:

Moral Identity

JEL Codes:
M1
Contextual Performance

M19
Organizational Identification

D23

\footnotetext{
1 Bu çalışma 23-25 Eylül 2020 tarihlerinde Erciyes Üniversitesi'nde düzenlenen 19. Uluslararası İşletmecilik Kongresi'nde sunulan bildirinin geliştirilmiş ve genişletilmiş halidir.

2 Prof. Dr. Erciyes Üniversitesi, İiBF, İşletme Bölümü, akdogana@erciyes.edu.tr, https://orcid.org/0000-0001-7373-4556

${ }^{3}$ Doç. Dr., Erciyes Üniversitesi, İ̈BF, İşletme Bölümü, aysecingoz@erciyes.edu.tr,

${ }^{4}$ Doç. Dr., Niğde Ömer Halisdemir Üniversitesi, İ̈BF, İşletme Bölümü, okoksal@ohu.edu.tr, https://orcid.org/0000-0001-7703-1807
}

Business \& Management Studies: An International Journal Vol.:8 Issue:4 Year:2020, 50-68 


\section{EXTENDED ABSTRACT}

\section{A STUDY ON DETERMINING THE RELATIONSHIPS AMONG MORAL IDENTITY PERCEPTION, CONTEXTUAL PERFORMANCE AND, ORGANIZATIONAL IDENTIFICATION}

\section{LITERATURE}

\subsection{RESEARCH SUBJECT}

Moral identity is a kind of regulatory mechanism that motivates and supports the moral behavior of individuals (Hart vd., 1998: 518; Hart vd., 1999: 376-377). Individuals with moral identity use concepts such as love, respect, tolerance, peace, compassion, and benevolence when defining themselves and the reasons for their behaviour in social life (Yılmaz ve Yılmaz, 2015: 112; Akdoğan vd., 2018: 937-338). Moral identity cannot be reduced to personality traits associated with prosocial behaviours such as resilience, conformity, conscience, or productivity, but it is also related to these concepts (Hart vd., 1998: 515). In particular, the attitudes and behaviours that are defined by these expressions or whose reasons are explained by these expressions, are attitudes and behaviours that are positive towards the organization and aimed at contributing. Organizational identification and contextual performance can be given as examples of attitudes and behaviours that are positively developed towards the organization and aimed at contributing. Contextual performance is voluntary behaviour that is performed beyond general expectations to encourage the effective operation of the organization or to benefit others in the organization (Lin vd., 2010: 358). Organizational identification, on the other hand, is the individual's definition of himself within the scope of the organization of which he is a member and feeling like a part of this organization (Mael ve Ashforth, 1992: 104-105; Turner, 1975: 6). Individuals with moral identity use positive emotions and expressions when defining themselves and the reason for their behaviour in social life. They could feel responsible for other individuals and events.

\subsection{RESEARCH PURPOSE AND IMPORTANCE}

The purpose of this study is to determine the regulatory role of organizational identification in the effect of moral identity perception on contextual performance. Determining the relationship between the concepts is essential in terms of both contributing to human resources applications such as career management and ensuring high performance of employees in line with organizational purposes.

\subsection{CONTRIBUTION of the ARTICLE to the LITERATURE}

It is known that moral identity perception affects individual attitudes and behaviours. However, in the literature, there is no study showing the effect of moral identity perception on organizational identification and contextual performance by considering these variables together. In this respect, it is thought that the study will contribute to the literature.

\section{DESIGN AND METHOD}

\subsection{RESEARCH TYPE}

This article is a research article. 


\subsection{DATA COLLECTION METHOD}

The data collection method used in the study is a questionnaire. Various statistical methods analyzed the data collected from the employees of industrial enterprises operating in Kayseri Organized Industrial Zone. Convenience sampling method was used to determine 165 participants.

\subsection{QUANTITATIVE / QUALITATIVE ANALYSIS}

In order to test the hypotheses of the research, the PROCESS 2.16 .3 process, which is based on the regression analysis of Hayes (2013), was used.

\subsection{RESEARCH HYPOTHESES}

The research has two main hypotheses.

$\mathrm{H}_{1}$ : Moral identity-Perception of moral identity has a positive effect on contextual performance.

$\mathbf{H}_{2}$ : Organizational identification has a regulatory role in the impact of moral identity on contextual performance.

\section{FINDINGS AND DISCUSSION}

As a result of the analysis, it was found that the contextual performance of employees with moral identity increased. This finding is similar to some research findings examining the relationship between moral identity and employee behaviour in the relevant literature (Aquino et al., 2009; Rupp et al., 2013). In this research, additional findings were obtained that could contribute to the theoretical and practical literature for understanding the relationship in question. In this sense, it has been found that the effect of moral identity on contextual performance decreases in cases where organizational identification is high, and the effect of moral identity on contextual performance increases when organizational identification is low. On the other hand, when moral identity and organizational identification are low, contextual performance is at the lowest level. Despite the positive effect of moral identity and organizational identification on contextual performance separately, when the multiplicative effect of these two variables is concerned, the effect of moral identity on contextual performance differs according to the level of organizational identification.

\section{CONCLUSION, RECOMMENDATION AND LIMITATIONS}

As a result of the analysis, it has been found that the effect of moral identity perception on contextual performance decreases in individuals experiencing a high level of organizational identification, and the effect of moral identity perception on contextual performance increases in individuals who are identified with low-level organizational identification. The findings are discussed in the context of the relevant literature. Two main constraints can be mentioned within the scope of the research. Collecting the data obtained through the questionnaire from a single source (the individual himself) causes bias, which can lead to subjectivity in measurements. Thus, the size of the linear relationships emerging as a result of the analysis may increase (Podsakoff et al., 2003). Collecting data from different sources in future research may prevent this limitation. Another limitation is that this study is a cross-sectional study. Since cross-sectional research is a field study conducted in a specific time frame, it is not always possible to conclude the causal relationships between variables. Therefore, in future studies, instead of collecting data in a specific period, this constraint can be prevented by a longitudinal research design and the causal relationships between variables can become more reliable. In this study, the regulatory role of organizational identification in explaining the effect of moral identity perception on contextual performance is examined. The research model can be developed further by adding a new one to the research variables in future studies. Besides, the mediator and regulatory roles of other variables that are thought to have an impact on contextual performance can be examined. 


\section{GİRIŞ}

Ahlak kimlik, bireylerin ahlakî davranışlarını motive eden ve destekleyen bir tür düzenleme mekanizmasıdır (Hart vd., 1998: 518; Hart vd., 1999: 376-377). Ahlakî kimlik, bir dizi ahlakî özellikler çerçevesinde oluşturulmuş benlik algısı şeklinde de tanımlanabilir (Aquino ve Reed; 2002: 1424). Ahlakî kimliğe sahip bireyler kendilerini ve sosyal yaşam içindeki davranışlarının nedenini tanımlarken sevgi, saygı, hoşgörü, barış, merhamet ve yardımseverlik gibi kavramları kullanmaktadırlar (Yılmaz ve Yılmaz, 2015: 112; Akdoğan vd., 2018: 937-338). Ayrıca, benlik kavramları içerisinde ahlakî kimlikleri merkezi konumda olan bireyler, diğer bireylere ve olaylara karşı sorumluluk hissedebilmekte ve daha fazla ahlakî davranışa motive olabilmektedirler (Aquino ve diğerleri, 2009: 135). Ahlakî kimlik, dayanıklılık, uyumluluk, vicdan veya üretkenlik gibi toplum yanlısı davranışlarla bağlantılı kişilik özelliklerine indirgenemez ama bu kavramlarla da ilişkilidir (Hart vd., 1998: 515). Özellikle örgüt içinde bu ifadelerle tanımlanan veya sebebi bu ifadelerle açıklanan tutum ve davranışlar örgüte karşı pozitif olan ve katkı sağlamaya yönelik tutum ve davranışlardır. Örgüte karşı pozitif şekilde geliştirilen ve katkı sağlamaya yönelik olan tutum ve davranışlara örgütsel özdeşleşme ve bağlamsal performans örnek olarak verilebilir.

Bağlamsal performans genel beklentilerin ötesinde, organizasyonun etkin şekilde işleyişini teşvik etmek veya organizasyondaki diğer kişilere fayda sağlamak için gerçekleştirilen isteğe bağlı olan davranışlardır (Lin vd., 2010: 358). Örgütsel özdeşleşme ise, bireyin kendisine dair tanımlamayı üyesi olduğu örgüt kapsamında yapması ve kendisini bu örgütün bir parçası olarak hissetmesidir (Mael ve Ashforth, 1992: 104-105). Bu kavramlar arasındaki ilişkinin ortaya konması, hem örgütsel açıdan kariyer yönetimi gibi insan kaynakları uygulamalarına katkı sağlaması hem de örgütsel amaçlar doğrultusunda iş görenlerin yüksek performans sağlamaları açısından önemlidir. Bu kapsamda yapılan bu çalışmanın amacı, ahlakî kimlik algısının bağlamsal performans üzerindeki etkisinde örgütsel özdeşleşmenin düzenleyicilik rolünü tespit etmektir. Ahlakî kimlik algısının bireysel tutum ve davranışlar üzerinde etkili olduğu bilinmektedir. Ancak literatürde, bu değişkenleri bir arada ele alarak, ahlakî kimlik algısının örgütsel özdeşleşme ve bağlamsal 
performans üzerinde nasıl bir etkiye sahip olduğunu gösteren bir çalışmaya rastlanmamıştır. Bu yönüyle, yapılan çalışmanın literatüre katkı sağlayacağı düşünülmektedir.

\section{KAVRAMSAL ÇERÇEVE VE HİPOTEZLER}

Bireylerin farklı değişkenler itibarıyla yaptıkları sosyal sınıflama doğrultusunda birçok sosyal kimliğe sahip oldukları söylenebilir. Tüm bu sosyal kimlikler benlik şemalarını (self-schema) oluşturmaktadır. Sosyal kimlikleri organize eden benlik şeması, bireyin sosyal kimliklerini benliğiyle ilişkilendiren, zihninde özel olarak yapılandırılmış ve bireye özgü bilgi yapısını ifade etmektedir. Bu yapı, farklı özelliklerdeki (farklı kişilik özelliği ya da farklı cinsiyet gibi) bireylerde farklı düzeylerde oluştuğundan elde edilen bilgi de bireye özgü olmaktadır. Bu noktada, bireye özgü bilginin gelişmesinde bireyin sahip olduğu ahlakî özelliklerin önemli bir payı olduğu söylenebilir. Böylece ahlakî kimlik, bireyin benlik şemasının bir parçası olarak sosyal kimliğin özel bir formu şeklinde ortaya çıkmaktadır (Aquino ve Reed, 2002: 1424). Ahlakî kimlik, ahlakî davranışları motive eden bir çeşit düzenleme mekanizmasıdır (Hart vd., 1998: 518; Hart vd., 1999: 376-377). Ahlakî kimlik, bir dizi ahlakî özellikler çerçevesinde oluşturulmuş benlik algısı şeklinde de tanımlanabilir (Aquino ve Reed; 2002: 1424). Ahlakî davranışları teşvik etmesinden ve ahlakî olmayan davranışlara engel olmasından dolayı kavram literatürde önemli bir konu haline gelmiştir (Y1lmaz ve Y1lmaz, 2015: 111).

Ahlakî kimlik, benlik sistemleri ile tutarlı, davranışı motive eden içsel insan eğilimine dayandırılır. Dolayısıyla ahlakî kimlik, bireyin kimliğinde merkez olan ahlakî değerlerin, meziyetlerin derecesi olarak kavramsallaştırılmaktadır. Yani buna göre benlik, ahlakî değerler ile yapılandırıldığında ya da tanımlandı̆̆ında ahlakî kimliğin oluşması mümkün olabilmektedir (Kocabıyık, 2014: 364). Ahlakî kimlik, bireylerin kendi ahlakî değerlerine-özelliklerine ilişkin sahip oldukları bilişsel şemalardır. Bu bilişsel şemalardan daha belirgin olanlar, bireyin duygu, düşünce ve davranışlarını etkileme konusunda ciddi bir potansiyele sahiptir (Aquino vd., 2007: 387). 
Birey açısından ahlakî kimlik; ahlakî değerlerin, amaçların ve erdemlerin ne denli önemli olduğuyla ilgilidir (Aquino ve diğerleri, 2009: 135; Kocabıyık, 2017: 266). Ahlakî kimliğin iki temel boyutu vardır. Bunlar; içselleştirme ve sembolleştirmedir. İçselleştirme yoluyla zihinde oluşturulan ahlakî şemalar, ahlakî birer kimlik özelliği olarak birey tarafından güçlü bir şekilde benimsenmektedir. Sembolleştirmede ise ahlakî kimlik özellikleri, toplum içinde sergilenerek kişisel eylemler olarak başkalarına yansitılmaktadır (Shao vd., 2008: 516-517; Y1lmaz ve Y1lmaz, 2015: 113). Dolayısıyla, ahlakî kimliğin içselleştirme boyutu bireyin ahlakî kimlik açısından kendini nasıl gördüğü ile alakalı iken, sembolleştirme boyutu ahlakî kimlik açısından bireyin başkaları tarafından nasıl algılandığı ile alakalıdır denilebilir. Ahlakî kimliğin bu iki boyutu ahlakî davranışları çeşitli şekillerde etkileyebilmektedir. Özellikle içselleştirme boyutu, ahlakî davranışlar için önemli bir öncül olarak görülmektedir ve bireylerin içselleştirdikleri ahlakî amaç, ideal ve değerlere göre hareket ettikleri ifade edilmektedir (Y1lmaz ve Yilmaz, 2015: 113).

Ahlakî kimlik farklı içeriklerden oluşabilmektedir. Bir birey şefkati, merhameti ahlakî kimliğinin merkezi olarak görebilirken bir diğer kişi ise adaletli ve dürüst olmayı ahlakî kimliğinin merkezinde görebilmektedir. Bu nedenle, ahlakî kimlik bireysel farklılıkların bir boyutu olarak kabul edilebilmektedir. Benlik kavramları içerisinde ahlakî kimlikleri daha az merkezi konumda olan bireyler, diğger bireylere ve olaylara karşı sorumluluk hissetmeyebilir. Dolayısıyla, bu bireylerin daha az ahlakî davranışa motive olacakları düşünülmektedir. Bunun anlamı, bu bireylerin diğer bireylerin ihtiyaçlarına ve ilgilerine daha az duyarlı olmalarıdır (Aquino ve diğerleri, 2009: 135; Kocabıyık, 2017: 266). Bu çerçevede, ahlakî kimliğe sahip bir bireyin, kendi kimliğini tanımlarken ve gündelik hayattaki davranışlarını açıklarken, öncelikle kendi zihninde oluşturduğu ahlakî şemalara başvurduğu söylenebilir. Bu yüzden, ahlakî kimliğe sahip bir bireyin kendini tanımlarken sevgi, saygı, hoşgörü, barış, merhamet ve yardımseverlik gibi kavramları kullanacağı, sosyal yaşam içindeki davranışlarının

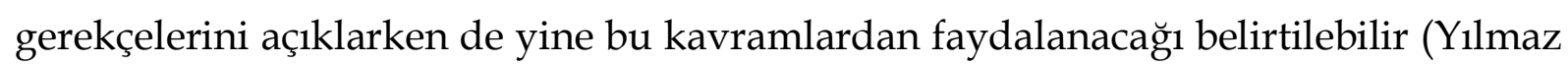
ve Y1lmaz, 2015: 112; Akdoğan vd., 2018: 937-338).

Görüldüğü üzere bireyin kendine yönelik sahip olduğu ahlakî kimlik algısı, bireyin duygu, düşünce ve davranışları üzerinde etkili olduğu gibi bireyin kendini 
tanımlama şeklini de etkilemektedir. Eğer bir birey kendini tanımlarken yardımseverlik ve hoşgörü gibi ifadeleri-tanımlamaları kullanıyorsa, bu bireylerin örgüte katkı sağlama yönünde sergileyeceği davranışların artma ihtimali yüksektir. Gönüllülük esasına dayalı olarak örgüte katkı sağlamaya yönelik davranışlardan biri bağlamsal performanstır.

Bağlamsal performans, organizasyonun teknik merkezi işlevini yerine getirmesini sağlayan faaliyetlere ek olarak; çalışma ortamının organizasyonel, sosyal ve psikolojik havasını zenginleştiren çalışmalara işaret etmektedir (Ünlü ve Yürür, 2011: 185). Dolayısıyla bağlamsal performans genel beklentilerin ötesinde, organizasyonun etkin şekilde işleyişini teşvik etmek veya organizasyondaki diğer kişilere fayda sağlamak için gerçekleştirilen, isteğe bağlı olan, resmi ödül sistemi tarafından doğrudan veya açıkça tanınmayan-tanımlanmayan bireysel bir davranıştır (Lin vd., 2010: 358). Bu noktada, temel sorumluluklar dişındaki faaliyetlere gönüllü katılma, hevesle, sebat ederek ve çaba göstererek bir işi başarıyla tamamlamaya çalışma, çalışma arkadaşlarına yardım etme, iş birliği oluşumuna katkıda bulunma, her koşulda örgüt kurallarına uyma, örgütsel amaçları benimseme gibi örgüt kültürüne ve iklimine katkıda bulunan davranışlar bağlamsal performans kapsamında değerlendirilebilmektedir (Yıldız ve Çakı, 2018: 72). Görüldüğü üzere bağlamsal performans, çalışanın yapmakla yükümlü olduğu asli görevinin yerine getirilmesi ile doğrudan ilgili olmayan, fakat örgütün sosyal ve psikolojik ortamını etkilediği için değerli kabul edilen görev, faaliyet ve süreçlerin destekçisi olan kişisel çabaları kapsamaktadır (Yorulmaz, 2018: 352).

Bağlamsal performansın, kişilerarası kolaylaştırıcılık ve işe adanma şeklinde iki temel boyutu söz konusudur (Ünlü ve Yürür, 2011: 185). Kişilerarası kolaylaştırıcılık; çalışma arkadaşlarının performanslarını da destekleyen, anlayışlı, birlikte çalışmaya yatkın, yardımsever eylemlerden oluşmaktadır. Diğerlerini gözetme, hassasiyet ve sevecenlik gibi faktörler de kişilerarası kolaylaştırıcılık kapsamında girmektedir. İşe adanma ise, iş yerinde karşılaşılan sorunları çözmek ve örgüte katkı sağlamak için motive olmuş bir şekilde çok çalışma, inisiyatif alma ve belirlenen hedeflere ulaşma noktasında kurallara uyma gibi öz disipline dayanan davranışları ifade etmektedir. $\mathrm{Bu}$ bağlamda çalışanlar, iş arkadaşlarıyla iyi ilişkiler kurduğunda, işleri için onlara 
yardımcı olduklarında, iş yerinde karşılaşılan sorunları çözmek ve işi zamanında tamamlamak için motive olmuş bir şekilde çaba sarf ettiklerinde bağlamsal performans sergilemiş olurlar. Rol dışı performans veya ekstra rol davranışı olarak da ifade edilen bağlamsal performans, örgütsel amaçlara ulaşmada sosyal ve psikolojik faktörleri kapsamaktadır. Bağlamsal performansın bu özellikleri nedeniyle, görev performansının olumlu biçimde gerçekleşebilmesi için gerekli olan örgüt ikliminin oluşmasına katkı sağladığı da ifade edilebilir (Yorulmaz, 2018: 352).

Yukarıda da ifade edildiği gibi, ahlakî kimliğe sahip bireyler kendilerini ve sosyal yaşam içindeki davranışlarının sebebini tanımlarken pozitif duygu ve ifadeleri kullanmaktadırlar (Yılmaz ve Yılmaz, 2015: 112; Akdoğan vd., 2018: 937-338). Ayrıca, benlik kavramları içerisinde ahlakî kimlikleri merkezi konumda olan bireyler, diğer bireylere ve olaylara karşı sorumluluk hissedebilmekte ve daha fazla ahlakî davranışa motive olabilmektedirler. Bunun anlamı, bu bireylerin diğerlerinin ihtiyaçlarına ve ilgilerine daha fazla duyarlı olmalarıdır (Aquino ve diğerleri, 2009: 135). Özellikle örgüt içinde bu tarz olumlu ifadelerle tanımlanan veya sebebi bu ifadelerle açılanan davranışlar örgüte katkı sağlamaya yönelik davranışlardır. Ahlakî kimlik, dayanıklılık, uyumluluk, vicdan veya üretkenlik gibi toplum yanlısı davranışlarla bağlantılı kişilik özelliklerine indirgememekle birlikte bu kavramlarla da ilişki içindedir (Hart vd., 1998: 515). Bu bağlamda araştırmanın ilk hipotezi şu şekildedir.

$H_{1}$ : Ahlakî kimliğin-kimlik algısının bağlamsal performans üzerinde pozitif yönde etkisi vardır.

Sosyal özdeşleşme olgusunun örgüt ortamında ele alınmasıyla gelişen örgütsel özdeşleşme kavramının anlaşılması için öncelikle sosyal özdeşleşme konusunun açıklanması ve anlaşılması gerekir. Sosyal özdeşleşmenin geri planında sosyal kimlik kavramı yer alır. Kimlik bir kişinin kendisini, kendine ve başkalarına tanıtmak için kullandığı, mantıklı bir bağlantıya sahip ifadeler kümesidir. Bir bireyin kimliği sadece onun kişisel nitelikleri açısından tanımlanmaz. Bireyin çeşitli gruplardaki üyeliği de onun kimliğinin oluşmasında etkilidir. Dolayısıyla bireyin kişisel kimliğinin yanı sıra, diğer sosyal kategorilerle bağlantılı olarak edinmiş olduğu, sosyal bir kimliği de vardır (İşcan ve Karabey, 2015: 48). Sosyal Kimlik Teorisine (Ashforth ve Mael, 1989) göre bireyler kendilerini ve diğer bireyleri; örgüt üyeliği, akran ya da benzer yaş grubu gibi 
faktörler itibarıyla sınıflama eğilimindedirler. Farklı bireyler, farklı sınıflama planları kullanmaktadırlar. Sınıflama, bireylere, sosyal çevrelerini düzenleme ve bu çevreye kendileri ile diğer bireyleri konumlandırma imkânı vermektedir. Bu anlamda Sosyal Kimlik Teorisi, bireylerin, grup üyelerine atfedilen prototip özelliklere göre sinıflama yaptıklarını ileri sürmektedir. Yaptıkları sınıflama ile sosyal konumlarını belirginleştiren bireyler bu sayede öz-saygılarını artırmayı amaçlamaktadırlar. Bu durum, sosyal kimliğin ilişkisel ve kıyaslamalı doğası göz önüne alındığında anlaşılabilir bir durumdur. Bireyin grup dâhilinde ilişki içinde olduğu diğer üyelerle yaptığı grup içi pozitif ya da negatif kıyaslama öz-saygısını etkilemektedir. Ayrıca Sosyal Kimlik Teorisi bireylerin, kimliklerinin dikkat çeken yönleriyle uyumlu faaliyetleri tercih etme ve kimliklerine uygun davranışlar sergileyebilecekleri grupları destekleme eğiliminde olduğunu belirtmektedir. Bu bağlamda ileri sürülen sosyal özdeşleşme, diğger bir ifadeyle grupla özdeşleşme bireyin, sınıflandırması yapılmış bir gruba yönelik aidiyet algısını ifade etmektedir. Buna göre bireyler, kendilerini grubun gerçek veya potansiyel üyesi olarak algılamaktadırlar. Sosyal özdeşleşme çerçevesinde bireyler, grubun kaderi ile kendi kaderlerini iç içe geçmiş olarak algılamakta, ortak bir kaderi paylaştıklarına inanmakta ve böylece üyesi oldukları grubun başarı ve başarısızlığını kendi bireysel başarı ve başarısızlıklarıyla bağdaştırmaktadırlar. Dolayısıyla, sosyal özdeşleşme sayesinde bireyler, "ben kimim" sorusuna cevap bulma imkânına sahip olmaktadırlar. Bu anlayışla özdeşleşme, bireylerin grup üyelikleri ile birlikte, tek başlarına elde edebileceği başarıların ötesine geçmelerine imkân sağlamaktadır. Öyle ki özdeşleşme, öz-benliklerinin gelişimine katk1 sağladığ1 ölçüde bireylere zarar verecek faaliyetlerin dahi gerçekleştirilebileceğine, grubun diğer üyelerinin sevilmediği ya da grup başarısızlığının olası olduğu durumlarda dahi bireylerin faaliyetlerine neden ssrarla devam ettiğine açıklama getirmektedir. Bu çerçevede örgütsel özdeşleşme, sosyal özdeşleşmenin özel bir formu olarak göze çarpmaktadır. Bilişsel bir tutum olan örgütsel özdeşleşme, bireyin kendisine dair tanımlamayı üyesi olduğu örgüt kapsamında yapması ve kendisini bu örgütün bir parçası olarak hissetmesini ifade etmektedir (Mael ve Ashforth, 1992: 104-105; Turner, 1975: 6). Örgütsel özdeşleşme, bireyin örgütsel değer ve inançları benimsemesi, örgütün inanç ve değerlerini kendi 
inanç ve değerleri ile özdeşleştirmesi şeklinde de ifade edilebilir (Carmeli vd., 2007: 974). Örgütsel özdeşleşme bireyin örgüte karşı geliştireceği çeşitli tutum ve davranışlara temel teşkil eder. Örgütsel özdeşleşme çalışan performansı, iş tatmini ve örgütsel bağlllık gibi değişkenlerle pozitif yönlü bir ilişki içindeyken, işe yabancılaşma ve işten ayrılma niyetiyle olumsuz şekilde ilişkilidir (İşcan ve Karabey, 2015: 56-57). Bu nedenle işletme yöneticileri, çalışanları örgütle özdeşleştirmenin, çalışanlara örgüt amaç ve değerlerini benimsetmenin yollarını araştırmakta ve çalışanlarıyla bu doğrultuda ilişki kurmaya çalışmaktadırlar.

Örgütsel özdeşleşme konusunu örgütler için önemli hale getiren bir nokta ise, çalışma ortamında duyguların öneminin yeniden ortaya çıkmasıdır. Çalışılan örgütler, bireylerin dahil olduğu grupların en önemlilerinden biridir ve bireyler bu örgütlerde diğerlerinde olduğundan daha fazla vakit geçirirler. Ayrıca bireyin geçimin sağlaması da bu örgütlerin geleceğine ve kişinin işteki rolünde başarılı olmasına bağlıdır. Bu tarz sosyal gruplarla özdeşleşme, bireylerin güvenlik ve aidiyet ihtiyaçlarını giderme özelliğine sahip olması açısından önemlidir. Bununla birlikte özdeşleşme, bireyin bütünlük ihtiyacını karşılar. Çünkü bireye anlam kazandırır ve bireyin kendi hayatını anlamlı bulmasına yardımcı olur. Bu sebeple özdeşleşme çalışanları birey olarak ilgilendirir, çalışanların duygu ve davranışlarını etkiler. Birey benlik tanımının bir parçası olarak örgüt üyeliğini içselleştirdiğinde bir anlam duygusu kazanır. İnsanların çalıştıkları örgütle özdeşleşmesi örgütün performansını, çalışanların mutluluğunu ve değişim dönemlerinde hem örgütlerin hem de bireylerin esnekliğini etkileyebilecek güce sahip bir bütünlük duygusu yaratmaktadır (İşcan ve Karabey, 2015: 59).

Örgütsel özdeşleşme, çalışanın sahip olduğu amaç hedeflerini çalışttğı örgütün amaç ve hedefleri ile uyumlaştırması, bağdaştırması ve bunun sonucunda çalışanın kendini örgütün bir parçası gibi hissetmesidir (Kanbur, 2017: 226). Bu anlamda örgütsel özdeşleşme, örgüt amaçları ile birey amaçlarının bütünleşmesini öngörmektedir. Öyle ki örgüt yaşamını sürdürdüğü sürece örgütleriyle özdeşleşmiş üyeler de yaşamlarını sürdürebilirler. Bu ilişki, bireylerin, tüm çabalarını çalışma arkadaşları ile örgütlerine yönlendirmelerine öncülük etmektedir. Örgütsel özdeşleşme düzeyleri yüksek bireylerin, özdeşleşme düzeyleri düşük olanlara kıyasla, iş performanslarının daha yüksek olduğu da söylenebilir (Carmeli vd., 2007; 977-978). 
Nitekim Walumbwa ve arkadaşları (2011) tarafından yöneticiler üzerinde yapılan araştırmada örgütsel özdeşleşmenin iş performansı ile pozitif yönde ilişkili olduğu bulunmuştur. Bunun yanında, Bergami ve Bagozzi (2000) tarafından gıda sektöründe faaliyet gösteren bir örgütün çalışanları üzerinde yapılan araştırmada örgütsel özdeşleşmenin örgütsel vatandaşlık davranışının önemli bir belirleyicisi olduğu ortaya çıkmıştır.

Görüldüğü üzere, belirli bir performans düzeyine ulaşmada bireyin dürüst, çalışkan, sadık ya da yardımsever gibi ahlakî özelliklere sahip olmasının yanı sıra, bireyin kendisini örgütün bir parçası olarak görmesinin de önemli bir rolü bulunmaktadır. Yüksek düzeyde örgütleriyle özdeşleşmiş bireyler, üyesi oldukları örgütün diğer örgütlerden ayırt edici birtakım özellikler kazanması sürecinde önemli bir paya sahip olmayı arzulamaktadırlar. Bu bakımdan, bu bireylerin rol tanımlarının ötesinde ekstra rol davranışları sergileme eğilimleri yükselmekte ve performansa giden süreçte ortaya koyacakları çaba diğerlerinden farklllaşabilmektedir. Bu ifadeler 1şığında araştırmanın ikinci hipotezini aşağıdaki şekilde belirtmek mümkündür:

$\mathbf{H}_{2}$ : Ahlakî kimliğin bağlamsal performans üzerindeki etkisinde örgütsel özdeşleşmenin düzenleyicilik rolü vardır.

\section{YÖNTEM}

\subsection{Katılımcilar}

Araştırma verileri 1 Ocak 2020 tarihinden önce toplanmıştır. Bu nedenle, etik kurul izin belgesi gerekmemektedir. Araştırmanın katılımcıları, Kayseri Organize Sanayi Bölgesinde bulunan sanayi işletmelerinde çeşitli kadrolarda görev yapan idari personel ile beyaz yakalı çalışanlardan oluşmaktadır. 165 katılımcının belirlenmesinde kolayda örnekleme yöntemi kullanılmıştır. Katılımcıların \%72,7'si erkek, \%27,3'üu kadındır. Eğitim durumları itibarıyla, katılımcıların \%41,8'inin ön lisans ve öncesi, \%55,2'sinin lisans, \%3’lük kısmının ise yüksek lisans düzeyinde eğitime sahip oldukları görülmüştür. Katılımcıların yaş ortalaması 34,52 yıl (s.s.= 7.16), örgütte çalışma sürelerinin ortalaması ise 7.26 yıldır (s.s.= 6.23). 


\section{2. Ölçüm Araçları}

\subsubsection{Ahlakî Kimlik}

Katılımcıların ahlakî kimlik algıları, Aquino ve Reed (2002) tarafından geliştirilen 10 maddelik Ahlakî Kimlik Ölçeği ile ölçülmüştür. 5’li Likert ölçeğine göre tasarlanan ölçekte yer alan maddelerden örnek madde; "Belirli kurumlardaki üyeliklerim, bu özelliklere (duyarlı, şefkatli, adil, arkadaş canlısı, cömert, yardımsever, çalışkan, dürüst, kibar) sahip biri olduğumu diğer insanlara gösterir" şeklindedir. Ölçeğin, Türkçe uyarlaması Yılmaz ve Yılmaz (2015) tarafından yapılmıştır. Bu çalışmada, ölçeğin Cronbach Alpha cinsinden güvenirlilik katsayısının ( ( ).78 olduğu görülmüştür.

\subsubsection{Bağlamsal Performans}

Katılımcıların bağlamsal performans düzeyleri, Goodman ve Svyantek (1999) tarafından geliştirilen 16 maddelik Bağlamsal Performans Ölçeği yardımıyla ölçülmüştür. Ölçeğe ilişkin örnek madde; "Sorumluluğum dâhilinde olmayan, fakat örgütümün imajına olumlu katkı yapacak faaliyetlere gönüllü olarak katılırım" şeklindedir. Bu ölçek, ulusal yazında yürütülen çeşitli araştırmalarda kullanılmıştır (Polatc1, 2014; Ünlü ve Yürür, 2011). Katılımcıların, Bağlamsal Performans Ölçeğinde yer alan maddeleri 5’li Likert ölçeğine göre cevaplamaları istenmiştir. Bu çalışmada, ölçeğin güvenilirliği için Cronbach Alpha cinsinden (a).87 değeri elde edilmiştir.

\subsection{3. Örgütsel Özdeşleşme}

Katılımcıların örgütleriyle özdeşleşme düzeylerinin ölçümünde Mael ve Ashforth (1992) tarafından geliştirilen 6 maddelik ölçek kullanılmıştır (örnek madde: “Herhangi biri çalıştığım kurumu eleştirdiğinde, bunu kendime yapılmış gibi hissederim"). Ölçekte yer alan maddelerin katılımcılar tarafından değerlendirilmesi 5'li Likert biçimindedir. Ulusal yazında pek çok araştırmada kullanılan ölçeğin (Tokgöz ve Seymen, 2013; Turunç ve Çelik, 2010), bu çalışmada, Cronbach Alpha cinsinden güvenirlilik katsayısı (a).92 olarak bulunmuştur. 


\section{BULGULAR}

Araştırma değişkenlerine ilişkin ortalama, standart sapma ve korelâsyon değerlerini gösteren bulgular Tablo 1'de yer almaktadır.

Tablo 1. Değişkenlerin Ortalama, Standart Sapma ve Korelâsyon Değerleri

\begin{tabular}{lccccccccc}
\hline Değişkenler & Ort. & S.S. & $\mathbf{1}$ & $\mathbf{2}$ & $\mathbf{3}$ & $\mathbf{4}$ & $\mathbf{5}$ & $\mathbf{6}$ & $\mathbf{7}$ \\
\hline 1. Cinsiyet & 1.72 & .44 & $(-)$ & & & & & & \\
2. Eğitim & 3.21 & 1.11 & -.06 & $(-)$ & & & & & \\
3. Yaş & 34.52 & 7.16 & $.41^{* *}$ & $-.22^{* *}$ & $(-)$ & & & & \\
4. Çalışma Süresi & 7.26 & 6.23 & $.26^{* *}$ & $-.19^{*}$ & $.66^{* *}$ & $(-)$ & & & \\
5. Ahlakî Kimlik & 4.02 & .55 & .09 & $.19^{*}$ & $.17^{*}$ & .11 & $(-)$ & & \\
6. Bağlamsal & & & & & & & & & \\
Performans & 4.02 & .56 & .09 & $.21^{* *}$ & .11 & .05 & $.59^{* *}$ & $(-)$ & \\
7. Örgütsel & & & & & & & & & \\
Özdeşleşme & 4.14 & .83 & .10 & $.21^{* *}$ & .14 & .02 & $.46^{* *}$ & $.65^{* *}$ & $(-)$ \\
\hline
\end{tabular}

${ }^{*} \mathrm{p}<.05,{ }^{* *} \mathrm{p}<.01$ Cinsiyet değişkeni (1) kadın (2) erkek şeklinde kodlanmıştır.

Tablo 1 incelendiğinde, katılımcıların eğitim düzeyleri ile ahlakî kimlikleri ( $\mathrm{r}=$ .19, $\mathrm{p}<.05)$, bağlamsal performansları $(\mathrm{r}=.21, \mathrm{p}<.01)$ ve örgütleriyle özdeşleşme düzeyleri $(r=.21, p<.01)$ arasında pozitif yönlü bir ilişki olduğu görülmüştür. Buna göre, katılımcıların eğitim düzeyleri yükseldikçe; ahlakî kimliklerinin, bağlamsal performanslarının ve örgütsel özdeşleşme düzeylerinin arttı̆̆ı söylenebilir. Bunun yanında, yaşın katılımcıların ahlakî kimlikleriyle $(r=.17, \mathrm{p}<.05)$ pozitif yönde ilişki içinde olduğu bulunmuştur. Bu çerçevede, katılımcıların yaşları ilerledikçe, ahlakî kimliklerinin güçlendiğini söylemek mümkündür. Ayrıca, ahlakî kimliğin bağlamsal performansla $(r=.59, p<.01)$ ve örgütsel özdeşleşmeyle $(r=.46, p<.01)$; bağlamsal performansın da örgütsel özdeşleşmeyle $(r=.65, p<.01)$ pozitif yönde ilişkili olduğu görülmüştür.

Araştırmanın hipotezlerini test etmek amaciyla Hayes'in (2013) regresyon analizine dayalı olarak çalışan PROCESS 2.16.3 işlemi kullanılmıştır. Önyükleme (bootstrap) yaklaşımına dayalı olarak (5000 örneklem) yapılan analizin bulguları Tablo 2'de yer almaktadır. Tablo 2 incelendiğinde, ahlakî kimlik $(b=1.39 \mathrm{p}<.001,0.9810<$ YD 95\% GA < 1.8098) ve örgütsel özdeşleşmenin ( $b=1.33$ p<.001, 0.9363 < YD 95\% GA 
< 1.7338) bağlamsal performans üzerinde anlamlı ve pozitif yönde etkisinin olduğu görülmüştür. Bu bulgu, araştırmanın birinci hipotezine destek sağlamıştır. Bunun yanında, ahlakî kimlik x örgütsel özdeşleşme etkileşim değişkeni etkisinin anlamlı bulunması $(b=-.25 p<.001,-.3590<$ YD 95\% GA < -.1578), ahlakî kimliğin bağlamsal performans üzerindeki etkisinde örgütsel özdeşleşmenin düzenleyicilik rolünün bulunduğunu göstermiştir.

Tablo 2. Düzenleyicilik Analizi Sonuçları

\begin{tabular}{|c|c|c|c|c|}
\hline & \multirow[b]{2}{*}{$b$} & \multirow[b]{2}{*}{$S H$} & \multicolumn{2}{|c|}{ YD 95\% GA } \\
\hline & & & Alt Sinir & Üst Stnır \\
\hline Sabit & $-2.75^{* * *}$ & .80 & -4.3414 & -1.1724 \\
\hline Ahlakî Kimlik & $1.39 * * *$ & .20 & .9810 & 1.8098 \\
\hline Örgütsel Özdeşleşme & $1.33^{* * *}$ & .20 & .9363 & 1.7338 \\
\hline Ahlakî Kimlik X Örgütsel & $-.25^{* * *}$ & .05 & -.3590 & -.1578 \\
\hline Özdeşleşme & & & & \\
\hline
\end{tabular}

Ahlakî kimlik ve örgütsel özdeşleşmenin bağlamsal performans üzerindeki birlikte etkisinin biçimi ve yönü grafiksel olarak Şekil 1'de yer almaktadır. Ahlakî kimlik ile bağlamsal performans arasında pozitif yönlü bir ilişki vardır. Ancak, düşük düzeyde kendini örgütüyle özdeşleştirmiş bireyler için ahlakî kimlik ile bağlamsal performans arasındaki ilişki anlamlı ve pozitif yönlü iken $(b=.54, p<.001)$; yüksek düzeyde özdeşleşmiş bireyler için ahlakî kimlik ile bağlamsal performans arasında anlamlı bir ilişki yoktur ( $b=.11, p=.148)$. Buna göre, düşük düzeyde örgütsel özdeşleşme yaşayan bireylerde ahlakî kimliğin bağlamsal performans üzerindeki etkisi, yüksek düzeyde özdeşleşme yaşayan bireylere kıyasla daha güçlüdür. Bu çerçevede örgütsel özdeşleşmenin, ahlakî kimliğin bağlamsal performans üzerindeki etkisini belirli bir düzeyde düzenlediği anlaşılmaktadır. Bu bulgu, araştırmanın ikinci hipotezini desteklemiştir. 


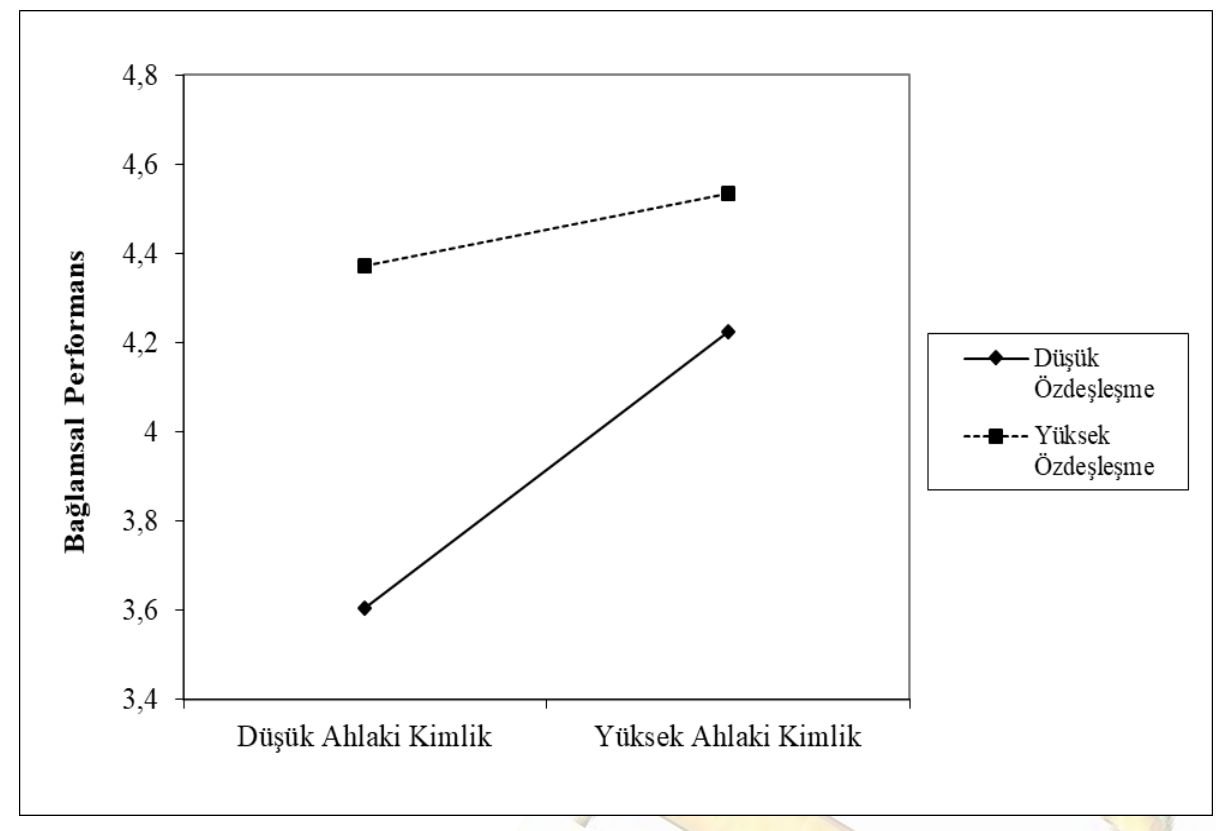

Şekil 1. Örgütsel Özdeşleşmenin Düzenleyicilik Rolünün Grafiksel Gösterimi

\section{SONUÇ VE TARTIŞMA}

$\mathrm{Bu}$ çalışma kapsamında, ahlakî kimliğin bağlamsal performans üzerindeki etkisinde örgütsel özdeşleşmenin düzenleyicilik rolünü tespit etmek amaçlanmıştır. Yapılan analizler sonucunda, ahlakî kimlik sahibi çalışanların bağlamsal performanslarının arttığı bulunmuştur. Bu bulgu, ilgili alan yazında ahlakî kimlik ile çalışan davranışları arasındaki ilişkiyi inceleyen bazı araştırma bulgularıyla benzerlik göstermektedir (Aquino vd., 2009; Rupp vd., 2013). Bu araştırmada söz konusu ilişkinin anlaşılmasına yönelik teorik ve pratik yazına katkı sağlayabilecek ek bulgular elde edilmiştir. Bu anlamda, örgütsel özdeşleşmenin yüksek olduğu durumlarda ahlakî kimliğin bağlamsal performans üzerindeki etkisinin azaldığı, örgütsel özdeşleşmenin düşük olduğu durumlarda ise ahlakî kimliğin bağlamsal performans üzerindeki etkisinin arttığı bulunmuştur. Buna göre, ahlakî kimlik ile örgütsel özdeşleşmenin karşılıklı ilişkisi bağlamsal performans için önemli bir motivasyon kaynağı haline gelmektedir. Şöyle ki, ahlakî kimlik ve örgütsel özdeşleşmenin yüksek olduğu durumlarda bağlamsal performansın yükselme eğiliminde olduğunu söylemek mümkündür. Diğer taraftan, ahlakî kimlik ve örgütsel özdeşleşmenin düşük 
olduğu durumlarda bağlamsal performans en düşük düzeydedir. Ahlakî kimlik ile örgütsel özdeşleşmenin bağlamsal performans üzerindeki ayrı ayrı pozitif etkisine rağmen, bu iki değişkenin çarpımsal etkisi söz konusu olduğunda, örgütsel özdeşleşmenin düzeyine göre ahlakî kimliğin bağlamsal performans üzerindeki etkisi farklılaşmaktadır. Bu anlamda, örgüte karşı düşüncelerinden emin olmayan bireylerin zihinlerinde bir belirsizlik meydana gelmekte, düşüncedeki belirsizlik çevreye uygun davranışlar hakkındaki beklentilerde belirsizliği tetiklemekte, belirsizlik koşullarında bireyler bilgiye ulaşma istekleri ile sezgi yeteneklerini ortaya çıkarmakta ve bu durum davranışlardaki bireysel farklılıklara güçlü bir şekilde etki etmektedir. Diğer taraftan, birey davranışları için net bir yol gösterici konumunda olan bilişsel yapının belirgin olduğu durumlar, bireysel yorumlama ve anlam çıarma süreçlerini minimize etmektedir. Böylece, güçlü bilişsel yapının bulunduğu koşullar altında bireysel farklılıkların etkisi zayıflamaktadır (He vd., 2014). Kısacası, bir birey örgütüyle özdeşleşmişse ahlakî kimlik algısına ihtiyaç duymaksızın yüksek bağlamsal performans sergileyebilmektedir. Buna karşın, örgütüne karşı zayıf duygular besliyorsa ancak ahlakî kimlik duygusu yüksek olan bireyler bağlamsal performans ortaya koyabilmektedir.

Araştırma kapsamında iki temel kısıttan bahsedilebilir. Anket aracılı̆̆ıyla elde edilen verinin tek bir kaynaktan (bireyin kendisi) toplanması yanlıllğa neden olmakta, bu durum ölçümlerde öznelliğe yol açabilmektedir. Böylece, analiz sonucunda ortaya çıkan doğrusal ilişkilerin büyüklüğü artabilmektedir (Podsakoff vd., 2003). İleride yapılacak araştırmalarda farklı kaynaklardan veri toplanması bu kısıtı engelleyebilir. Diğer bir kısıt ise bu araştırmanın kesitsel (cross sectional) bir araştırma olmasından kaynaklanmaktadır. Kesitsel araştırma, belirli bir zaman diliminde yapılan bir alan araştırması olduğu için değişkenler arasındaki nedensel ilişkilerden bir sonuç çıkarmak her zaman mümkün değildir. Bu nedenle, ileride yapılacak araştırmalarda, belirli bir zaman diliminde verilerin toplanması yerine, boylamsal (longitudinal) bir araştırma tasarımı ile bu kısıt engellenebilir ve değişkenler arasındaki nedensel ilişkiler daha güvenilir hale gelebilir. Bu çalışmada, ahlakî kimlik algısının bağlamsal performans üzerindeki etkisini açıklamada, örgütsel özdeşleşmenin düzenleyici rolüne bakılmıştır. Gelecekte yapılacak çalışmalarda araştırma değişkenlerine yenisi 
eklenerek, araştırma modeli daha da geliştirilebilir. Ayrıca, bağlamsal performans üzerinde etkisi olduğu düşünülen diğer değişkenlerin aracı ve düzenleyici rollerine bak1labilir. 


\section{KAYNAKÇA}

Akdoğan A. A., Cingöz A., \& Köksal O. (2018). Kurumsal sosyal sorumluluk ile bağlamsal performans arasındaki ilişkide ahlaki kimlik algısının aracılık rolü. Uluslararası Türk Dünyası Sosyal Bilimler Kongresi, Simkent, Kazakistan, 935-942

Aquino, K., Reed, A., Thau, S., \& Freeman, D. (2007). A grotesque and dark beauty: how moral 1dentity an $\mathrm{d}$ mechanisms of moral disengagement influence cognitive and emotional reactons to war. Journal of Experimental Social Psychology, 43, 385-392.

Aquino, K., Freeman, D., Reed, A., Lim, V. K. G., \& Felps, W. (2009). Testing a social-cognitive model of moral behavior: The interactive influence of situations and moral identity centrality. Journal of Personality and Social Psychology, 97(1), 123-141.

Aquino, K., \& Reed, A. (2002). The self-importance of moral identity. Journal of Personality and Social Psychology, 83(6), 1423-1440.

Ashforth, B. E., \& Mael, F. (1989). Social identity theory and the organization. Academy of Management Review, 14(1), 20-39.

Bergami, M., \& Bagozzi, R. P. (2000). Self-categorization, affective commitment and group self-esteem as distinct aspects of social identity in the organization. British Journal of Social Psychology, 39, 555577.

Carmeli, A., Gilat, G., \& Waldman, D. A. (2007). The role of perceived organizational performance in organizational identification, adjustment and job performance. Journal of Management Studies, 44(6), 972-992.

Goodman, S. A., \& Svyantek, D. J. (1999). Person-organization fit and contextual performance: Do shared values matter. Journal of Vocational Behavior, 55, 254-275.

Hart, D., Atkins, R., \& Ford, D. (1998). Urban American as a context for the development of moral identity in adolescence. Journal of Social Issues, 54(3), 513-530.

Hart, D., Atkins, R., \& Ford, D. (1999). Family Inluences on the Formation of Moral Identity in Adolescence: Longitudinal analyses. Journal of Moral Education, 28(3), 375-386.

Hayes, A. F. (2013). Introduction to mediation, moderation, and conditional process analysis: A regression-based approach. New York: Guilford Press.

He, H., Zhu, W., \& Zheng, X. (2014). Procedural justice and employee engagement: Roles of organizational identification and moral identity centrality. Journal of Business Ethics, 122, 681-695.

İşcan, Ö. , \& Karabey, C. N. (2015). Örgütsel özdeşleşme. A. Keser, G. Y1lmaz, S. Yürür (Ed.) içinde, Çalışma Yaşamında Davranış: Güncel Yaklaşımlar (s. 47-66), Kocael: Umuttepe Yayınları.

Kanbur, E. (2017). Pozitif örgütsel davranış. S. Polatcı, K. Özyer (Ed.) içinde, 21. Yüzyılda Örgütsel Davranış (s. 219-242), İstanbul: Beta Basım Yayım Dağıtım A.Ş.

Kocabıyık, O. O. (2014). Benlik ve ahlaki kimlik. Değerler Eğitimi Dergis,. 12(27), 261-280.

Lin, C. P., Lyau, N. M., Tsai, Y. H., Chen, W. Y., \& Chiu, C. K. (2010). Modeling corporate citizenship and its relationship with organizational citizenship behaviors, Journal of Business Ethics, 95, 357-372.

Mael, F. A., \& Ashforth, B. E. (1992). Alumni and their alma mater: A partial test of the reformulated model of organizational identification. Journal of Organizational Behavior, 13(2), 103-123.

Podsakoff, P. M., Mackenzie, S. B., Lee, J. Y., \& Podsakoff, N. P. 2003. Common method biases in behavioral research: A critical review of the literature and recommended remedies. Journal of Applied Psychology, 88, 879-903.

Polatcı, S. (2014). Psikolojik sermayenin görev ve bağlamsal performans üzerindeki etkileri: Polis teşkilatında bir araştırma. Ege Akademik Bakış, 14(1), 115-124. 
Rupp, D. E., Shao, R., Thornton, M. A., \& Skarlicki, D. P. (2013). Applicants' and employees' reactions to corporate social responsibility: The moderating effects of first-party justice perceptions and moral identity. Personnel Psychology, 66, 895-933.

Shao, R., Aquino, K., \& Freeman, D. (2008). Beyond moral reasoning: A review of moral identity research and its implications for business ethics. Business Ethics Quarterly, 18(4), 513-540.

Tokgöz, E., \& Seymen, O. A. (2013). Örgütsel güven, örgütsel özdeşleşme ve örgütsel vatandaşlık davranışı arasındaki ilişki: Bir devlet hastanesinde araştırma. Öneri, 10(39), 61-76.

Turner, J. C. (1975). Social comparison and social identity: Some prospects for intergroup behaviour. European Journal of Social Psychology, 5(1), 5-34.

Turunç, Ö., \& Çelik, M. (2010). Örgütsel özdeşleşme ve kontrol algılamalarının, çalışanların işten ayrılma niyeti ve iş performansına etkileri. Atatürk Üniversitesi İktisadi ve İdari Bilimler Fakültesi Dergisi, 24(3), 163-181.

Ünlü, O., \& Yürür, S. (2011). Duygusal emek, duygusal tükenme ve görev/bağlamsal performans ilişkisi: Yalova'da hizmet sektörü çalışanları ile bir araştırma. Erciyes Üniversitesi İktisadi ve İdari Bilimler Fakültesi Dergisi, 37, 183-207.

Walumbwa, F. O., Mayer, D. M., Wang, P., Wang, H., Workman, K., \& Christensen, A. L. (2011). Linking ethical leadership to employee performance: The roles of leader-member exchange, self-efficacy, and organizational identification. Organizational Behavior and Human Decision Processes, 115, 204-2013.

Yıldız, B., \& Çakı, N. (2018). Algılanan Örgütsel desteğin bağlamsal performans üzerindeki etkisinde bireysel şükranın aracı rolü. Pamukkale Üniversitesi Sosyal Bilimler Enstitüsü Dergisi, 32, 69-86.

Yılmaz, F., \& Yılmaz, F. (2015). Ahlaki kimlik ölçeği Türkçe formunun geçerlik ve güvenirlik çalışması. Celal Bayar Üniversitesi Sosyal Bilimler Dergisi, 13(4), 111-133.

Yorulmaz, M. (2018). Gemi adamlarının iş tatmini, görev ve bağlamsal performansları arasındaki ilişkiler. Journal of ETA Maritime Science, 6(4), 349-363. 